\title{
Analisis Kebutuhan dan Biaya Alat Berat untuk Pekerjaan Pemadatan Lapisan Permukaan Street-Race Circuit Mandalika
}

\author{
A. Fihani ${ }^{\text {a }}$, Hasyim ${ }^{\text {a }}$ dan I.D.M.A. Karyawan ${ }^{\mathrm{a} *}$ \\ aJurusan Teknik Sipil, Fakultas Teknik Universitas Mataram, Jl. Majapahit No.62, Gomong, Mataram 83115, Indonesia \\ *Corresponding author’s e-mail: dewaalit@unram.ac.id
}

Received: 21 November 2020; revised: 12 February 2021; accepted: 15 February 2021

\begin{abstract}
The Street-Race Circuit is being built in the Mandalika Tourism Special Economic Zone (KEK), Central Lombok, West Nusa Tenggara. The construction is targeted to be completed, before the MotoGP event on this circuit is implemented in 2021. One of the infrastructure related to this, which also really needs to be built to support the smooth running of the 2021 MotoGP is the development of access to the circuit location. The analysis carried out includes the calculation of heavy equipment productivity. Heavy equipment productivity is determined based on cycle times, production per hour, number of heavy equipment used, the amount of operating costs per hour. The analysis was carried out for the road surface layer work, namely the Asphalt Concrete Base Course (AC-BC) work. Based on the results of the analysis, it was found that the production for 1 unit of asphalt mixing plant (AMP) was 49.80 tons/hour and 9 units of dump trucks were 2.34 tons/hour. The spreader using the asphalt finisher can spread 109.18 tons/hour. As for the compactor, which is 18.55 tons/hour for 2 units of tandem rollers and 27.47 tons/hour for 1 unit of pneumatic tire roller. Other equipment is $9.96 \mathrm{~m}^{2} /$ hour for air compressor and 2.74 liter/hour for asphalt sprayer. Meanwhile, in the Asphalt Concrete Wearing Course (AC-WC) work, several tools have the same productivity as the AC-BC job, namely asphalt mixing plant, air compressor and asphalt sprayer. Meanwhile, 13 units of Dump Trucks amounted to 2,338 tons/hour, 1 unit of asphalt finisher of 72,787 tons/hour, 3 units of tandem rollers of 12,367 tons/hour, and 1 unit of pneumatic tire roller of 18.31 tons/hour. The total cost of using heavy equipment for road surface layer work is Rp. $4,967,657,344$. The total cost based on the contract document is Rp. 5,042,082,622. So that there is a difference in costs of Rp. $74,425,278$.
\end{abstract}

Keywords: heavy equipment, tool usage costs, tool productivity.

\begin{abstract}
Abstrak: Sirkuit Jalan Raya (Street-Race Circuit) dibangun di Kawasan Ekonomi Khusus (KEK) Pariwisata Mandalika, Lombok Tengah, Nusa Tenggara Barat (NTB). Pembangunan ini ditargetkan selesai sebelum dilaksanakannya perhelatan MotoGP pada sirkuit ini di Tahun 2021. Salah satu infrastruktur terkait hal tersebut, yang juga sangat perlu dibangun demi mendukung kelancaran MotoGP 2021 adalah pengembangan akses menuju lokasi sirkuit. Analisis yang dilakukan yaitu perhitungan produktivitas alat berat. Produktifitas alat ditentukan berdasarkan waktu siklus alat, produksi per jam, jumlah alat yang digunakan, besarnya biaya operasional per jam kerja. Analisis dilakukan untuk pekerjaan lapis permukaan jalan, yaitu pekerjaan Asphalt Concrete Base Course (AC-BC). Berdasarakan hasil analisis, didapatkan produksi untuk 1 unit asphalt mixing plant (AMP) adalah 49,80 ton/ jam dan 9 unit dump truck sebesar 2,34 ton/jam. Alat penghampar menggunakan asphalt finisher dapat menghamparkan 109,18 ton/jam. Sedangkan untuk alat pemadat, yaitu 18,55 ton/ jam untuk 2 unit tandem roller dan 27,47 ton/jam untuk 1 unit pneumatic tire roller. Alat lainnya adalah $9,96 \mathrm{~m}^{2} / \mathrm{jam}$ untuk air compressor dan 2.74 liter/ jam untuk asphalt sprayer. Sedangkan pada pekerjaan Asphalt Concrete Wearing Course $(A C-W C)$, beberapa alat memiliki produktifitas yang sama seperti pada pekerjaan $A C-B C$, yaitu asphalt mixing plant, air compressor dan asphalt sprayer. Sedangkan untuk 13 unit Dump Truck sebesar 2,338 ton/jam, 1 unit asphalt finisher sebesar72,787 ton/jam, 3 unit tandem roller sebesar12,367 ton/jam, dan 1 unit pneumatic tire roller sebesar 18,31 ton/ jam. Total biaya penggunaan alat berat pada pekerjaan lapis permukaan jalan adalah Rp. 4.967.657.344. Total biaya berdasarkan dokumen kontrak adalah sebesar Rp. 5.042.082.622. Sehingga terdapat selisih biaya sebesar Rp. 74.425.278.
\end{abstract}

Kata kunci: alat berat, biaya penggunaan alat, produktivitas alat.

\section{Pendahuluan}

Secara umum infrastruktur jalan dibangun sebagai prasarana untuk memudahkan mobilitas dan aksesibilitas kegiatan sosial ekonomi dalam masyarakat. Keberadaan jalan raya sangatlah diperlukan untuk menunjang laju pertumbuhan ekonomi, perdagangan serta sektor lainnya. Perkembangan infrastruktur yang semakin pesat mendorong adanya peningkatan dan pembangunan yang ada saat ini. Tidak dapat dipungkiri bahwa pembangunan yang ada saat ini tidak lepas dengan adanya alat bantu yang digunakan, yaitu alat berat [1-3].

Alat berat merupakan faktor penting di dalam proyekproyek konstruksi dengan skala yang besar [4-6]. Tujuan penggunaan alat berat tersebut untuk memudahkan manusia dalam mengerjakan pekerjaan sehingga hasil yang diharapkan dapat tercapai dengan lebih mudah pada waktu yang relatif lebih singkat. Dalam menggunakan alat-alat berat untuk pembuatan konstruksi jalan perlu diperhatikan jenis konstruksi jalan, alat-alat berat yang dipakai, pengetahuan tentang kapasitas dan kemampuan alat berat agar memenuhi syarat penggunaan yaitu tidak menimbulkan pemborosan tenaga kerja, modal, produktivitas serta memenuhi kebutuhan keselamatan.

Menurut Sokop, dkk (2018), produktivitas atau kapasitas alat adalah besarnya keluaran (output) volume pekerjaan tertentu yang dihasilkan alat per-satuan waktu [7]. Untuk memperkirakan produktivitas alat diperlukan faktor standar 
kinerja alat yang diberikan oleh pabrik pembuat alat, faktor efisiensi alat, operator, kondisi lapangan dan material.

Kesalahan dalam pemilihan alat berat dapat mengakibatkan proyek pekerjaan tidak lancar. Dengan demikian keterlambatan penyelesaian pekerjaan dapat terjadi yang menyebabkan biaya akan menbengkak. Produktivitas yang kecil dan tenggang waktu yang dibutuhkan untuk pengadaan alat lain yang lebih sesuai merupakan hal yang menyebabkan biaya yang lebih besar [8-10].

Usaha pembangunan maupun perbaikan jalan di wilayah Nusa Tenggara Barat saat ini tetap ditingkatkan, terutama di Pulau Lombok. Kemajuann yang dapat dilihat di Pulau Lombok adalah dengan adanya pembangunan sirkuit MotoGP bertaraf internasional dengan mengusung konsep sirkuit jalan raya (Street-Race Circuit) di KEK Mandalika, Kabupaten Lombok Tengah. Sehingga pembangunan jalan dilakukan untuk memudahkan akses menuju lokasi sirkuit Mandalika. Salah satu wilayah yang melakukan usaha pembangunan maupun perbaikan jalan adalah di wilayah KEK Mandalika. Proyek pembangunan jalan di Kawasan
Ekonomi Khusus (KEK) Mandalika merupakan proyek dari pemerintah guna mendukung kelancaran MotoGp 2021.

Salah satu pekerjaan yang membutuhkan perhatian dan penanganan khusus pada proyek pembangunan jalan adalah pekerjaan lapis permukaan jalan (surface). Pekerjaan lapis permukaan jalan mempunyai ketebalan dan kekakuan yang cukup untuk mengurangi tegangan/regangan akibat beban lalu lintas yang akan diteruskan ke lapisan di bawahnya yaitu base dan sub grade (tanah dasar) serta dapat menambah daya tahan perkerasan terhadap penurunan mutu sehingga secara keseluruhan menambah masa pelayanan dari konstruksi perkerasan. Untuk itu pekerjaan lapis permukaan jalan menjadi sangat penting.

\section{Metode Penelitian}

\subsection{Lokasi Penelitian}

Penelitian ini berada di daerah Kuta Mandalika Lombok Tengah, ruas E-R-S-T Ruas jalan yang dibangun merupakan infrastruktur pendukung Street-Race Circuit seperti pada Gambar 1.

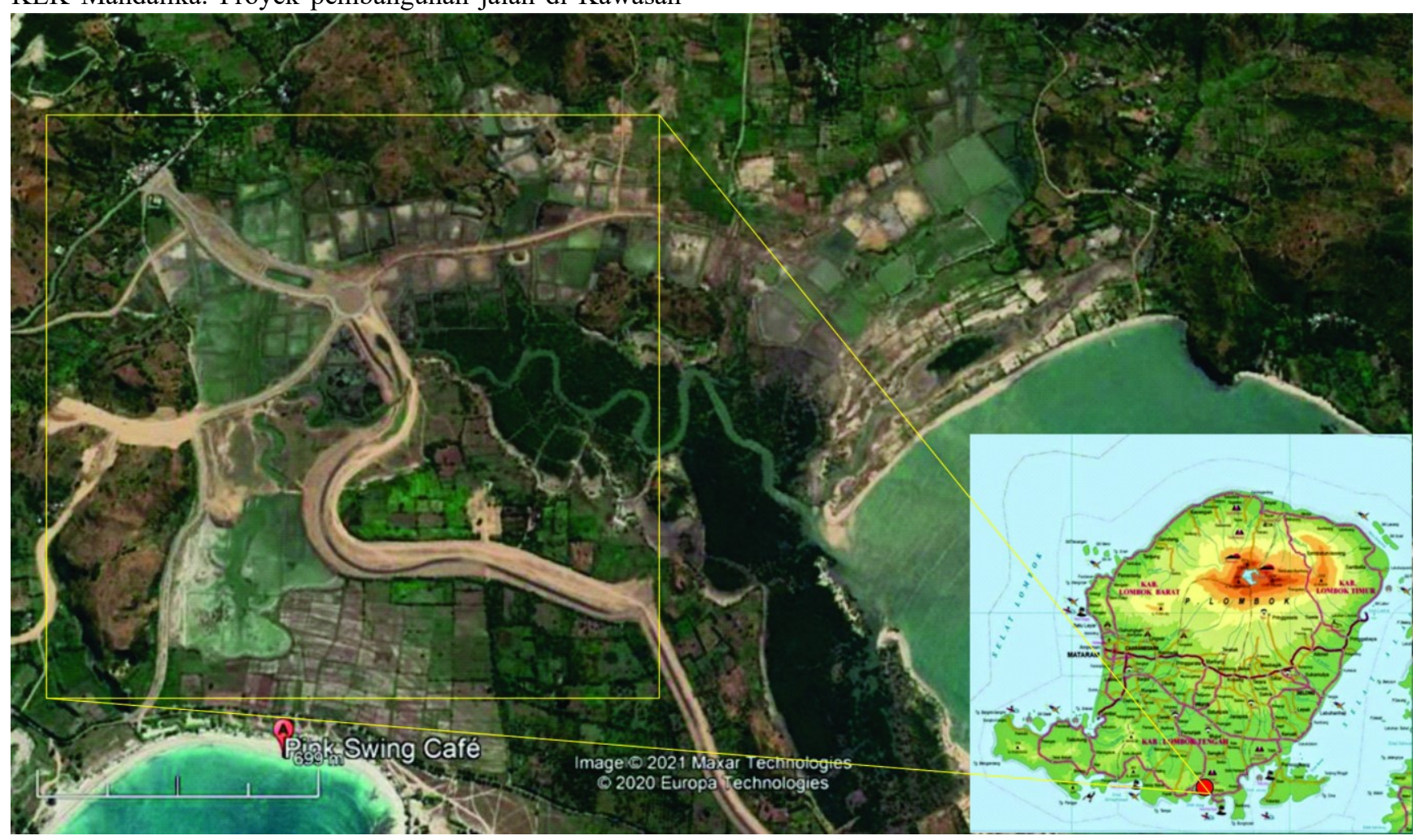

Gambar 1. Peta lokasi penelitian

\subsection{Data}

Data-data yang diperlukan, diperoleh dengan cara mencari informasi daripada instansi-instansi yang dianggap berkepentingan seperti dokumen kontrak, time schedule dan Kurva S, serta gambar kerja (shop drawing) di PT.WIKA BRL

\subsection{Metode dan Tahapan Penelitian}

Penelitian ini diawali dengan menentukan jenis alat berat serta menghitung produktivitas alat berat, menghitung total biaya sewa alat berat, menghitung harga satuan alat dan menghitung analisa harga alat dan profit [11-15].

1) Asphalt Mixing Plant (AMP)

Untuk menghitung produktivitas AMP digunakan rumus yaitu:

$Q=V F a$

2) Dump Truck

Untuk menentukan produktivitas dump truck dihitung menggunakan rumus yaitu:

$Q=\frac{V F a 60}{D T s}$ 
3) Air Compressor

Untuk menghitung produktivitas dari alat ini menggunakan rumus yaitu:

$Q=\frac{1.00 \mathrm{Fa} 60}{5}$

4) Asphalt Sprayer

Untuk menghitung produktivitasnya berdasarkan banyaknya pemakaian aspal menggunakan rumus yaitu:

$Q=P a F a 60$

5) Asphalt Finisher

Untuk menghitung produktivitas Asphalt Finisher menggunakan rumus yaitu:

$Q=v \quad b \quad F a 60$ t $D$

6) Tandem Roller

Untuk menghitung produktivitas Tandem Roller menggunakan rumus yaitu:

$Q=\frac{(\text { be } v \text { 1000) } t F a}{n}$

7) Pneumatic Tire Roller

Untuk menghitung produktivitas Pneumatic Tired Roller menggunakan rumus yaitu:

$Q=\frac{(\text { be } v \text { 1000) } t F a}{n}$

8) Menghitung Total Biaya Sewa Alat Berat

Adapun rumus-rumus yang digunakan untuk menghitung biaya sewa alat berat berdasarkan Bina Marga, antara lain:

a) Biaya Pasti Per Jam Kerja

- Nilai sisa alat dihitung menggunakan rumus yaitu

Nilai Sisa Alat $=10 \% \times$ Harga Alat

- Faktor angsuran modal dihitung menggunakan rumus:

$F A M=\frac{N i(1+i)^{A}}{(1+i)^{A}-1}$

- Biaya Pengembalian Modal dihitung menggunakan rumus yaitu:

$B P M=\frac{(\text { HA-NSA }) \times \text { F.Angsuran Modal })}{\text { Jam Ker ja dalam } 1 \text { Tahun }}$

- Asuransi dihitung menggunakan rumus yaitu

Asuransi $=\frac{0,002 x \mathrm{H} A}{\text { Jam Kerja dalam } 1 \text { Tahun }}$

- Biaya pasti per jam dihitung menggunakan rumus yaitu

$B P=P M+$ Asuransi

b) Biaya Operasi Per Jam Kerja [16-20]

- Biaya bahan bakar dihitung menggunakan rumus yaitu:

$B B=(12 \%-15 \%) P w M s$

- Biaya bahan bakar pemanasan material (khusus AMP) dihitung menggunakan rumus yaitu:

$B A M P=12$ ltr $x 0,7 \mathrm{Cp} M s$

- Biaya bahan bakar pemanas aspal dihitung menggunakan rumus yaitu:

$$
B B P A=\frac{1 C a M s}{1000}
$$

- Biaya pelumas dihitung menggunakan rumus yaitu:

Pelumas $=(2,5 \%-3 \%) P w M p$

- Biaya bengkel dihitung menggunakan rumus yaitu:

$B B=\frac{(6,25 \% \text { dan } 8,75 \%) H A}{\text { Jam Kerja dalam } 1 \text { Tahun }}$

- Biaya perawatan dan perbaikan dihitung menggunakan rumus yaitu:

$P D P=\frac{(12,5 \% \text { dan } 17,5 \%) H A}{\text { Jam Ker ja dalam } 1 \text { Tahun }}$

- Biaya Operator dihitung menggunakan rumus yaitu:

Operator $=(1$ orang $/ \mathrm{jam}) U 1$

- Biaya pembantu operatordihitung menggunakan rumus yaitu:

$P O=(1 \mathrm{orang} / \mathrm{jam}) \mathrm{U} 2$

- Biaya operasi per jam dihitung menggunakan rumus yaitu:

$B O=\sum B B+$ Pelumas +

Biaya Bengkel $+B P P+B O+B P O$

- Total Biaya Sewa Alat Per Jam Kerja

Total biaya sewa alat per jam kerja dihitung menggunakan rumus:

Total $=B P+B O$

9) Harga Satuan Alat

Harga satuan pekerjaan didapatkan dengan persamaan sebagai berikut (Panduan Analisis Harga Satuan Direktorat Jendral Bina Marga Departemen Pekerjaan Umum).

Upah : upah x koefisien (analisa upah)

Bahan : harga bahan x koefisien (analisa bahan)

Alat : harga sewa alat $\mathrm{x}$ koefisien (analisa alat)

10) Analisa Harga Alat dan Profit

Jumlah harga total pekerjaan dan profit dapat diperoleh dengan menggunakan persamaan sebagai berikut:

$$
\begin{aligned}
& \text { JHTP }=\text { Jumlah Harga }+ \text { PPN }+ \text { Profit } \\
& \text { Profit }=10 \% x(\text { Jumlah Harga }+P P N)
\end{aligned}
$$

\section{Hasil dan Pembahasan}

\subsection{Gambaran Umum Proyek}

Gambaran umum proyek pembangunan infrastruktur pendukung Street - Race Circuit Mandalika adalah sebagai berikut :

Nama Pekerjaan : Pekerjaan Konstruksi Infrastruktur Jalan, Jaringan Utilitas Air Bersih, Air Kotor, Air Irigasi Dan JaringanListrik Kawasan Mandalika 2018

Lokasi : : Lombok, Nusa Tenggara Barat 
Kontraktor

: PT. Wijaya Karya (PERSERO) Tbk.PT. Bunga Raya Lestari, KSO

1) Data Pekerjaan Pembangunan Jalan Ruas E-R-S-T Berdasarkan gambar kerja (shop drawing) yang diperoleh dari PT. WIKA BRL, maka diketahui :

Panjang : 2,5 kilometer

Lebar : 50 meter

2) Volume Pekerjaan Ruas E-R-S-T

Dari dokumen daftar kuantitas dan harga kontrak didapatkan besar volume pekerjaan pada ruas E-R-S-T adalah sebagai berikut :

- Volume Laston Lapis Antara ( AC-BC): 3.554,61 ton

- Volume Laston Lapis Aus ( AC-WC) : 3.334,86 ton

- Volume Lapis Resap Pengikat - Aspal Cair: 30.643,20 liter

- Volume Lapis Perekat - Aspal Cair: 14.374,40 liter

3) Data Primer

Dari hasil pengamatan/survey di lapangan diperoleh data-data sebagai berikut:

- Durasi pekerjaan dalam 1 hari: 8 jam

- Jarak AMP yang berlokasi di Pringgabaya Kabupaten Lombok Timur ke lokasi proyek: 75,08 $\mathrm{km}$

- Durasi pekerjaan lapis resap pengikat-aspal cair: 28 hari

- Durasi pekerjaan lapis perekat-aspal cair: 21 hari

- Durasi pekerjaan AC-BC: 21 hari

- Durasi pekerjaan AC-WC: 14 hari

4) Data Sekunder

- Jumlah harga pekerjaan lapis permukaan jalan ruas E-R-S-T berdasarkan dokumen kontrak adalah sebesar Rp 5.042.082.622

- Kecepatan alat berat dump truck berdasarkan tabel Bina Marga

- Standar satuan harga menggunakan standar Harga Provinsi NTB 2018

Tabel 1 dan Tabel 2 merupakan rekapitulasi hasil produktivitas, jumlah alat berat dan rencana durasi masingmasing alat berat pada dua jenis pekerjaan berbeda disesuaikan dengan kondisi yang ada di lapangan. Tabel 3 menyajikan perhitungan harga sewa alat berat. Produktivitas alat berat dipengaruhi oleh waktu siklus dan kecepatan alat berat.

Terkadang waktu siklus dump truck mengalami hambatan di jalan terutama saat dump truck sedang dalam kondisi bermuatan sehingga membutuhkan waktu yang cukup lama dalam proses angkutan. Produktivitas dan jumlah alat yang didapatkan dari hasil perhitungan untuk Pekerjaan Laston Lapis Antara (AC-BC) adalah 1 unit AMP sebesar 49,80 ton/jam, 9 unit dump truck masing-masing sebesar 2,338 ton/jam, 1 unit asphalt finisher sebesar 109,181 ton/jam, 2 unit tandem roller masingmasingsebesar 18,5505 ton/jam dan 1 unit pneumatic tire rollersebesar 27,467 ton/jam. Untuk pekerjaan lapis resap pengikat aspal cair didapatkan produktivitas dan jumlah alat yaitu, 1 unit air compressor sebesar 9,96 $\mathrm{m}^{2} / \mathrm{jam}$ dan 1 unit asphalt sprayer sebesar 2.739 liter/jam. Untuk pekerjaan lapis perekat-aspal cair didapatkan produktivitas dan jumlah alat yaitu, 1 unit air compressor sebesar 9,96 $\mathrm{m}^{2} / \mathrm{jam}$ dan 1 unit asphalt sprayer sebesar 2.739 liter/jam. Sedangkan pada Pekerjaan Laston Lapis Aus (AC-WC) adalah 1 unit AMP sebesar 49,80 ton/jam, 13 unit dump truck masingmasing sebesar 2,338 ton/jam, 1 unit asphalt finisher sebesar 72,787 ton/jam, 3 unit tandem roller masingmasingsebesar 12,367 ton/jam dan 2 unit pneumatic tire roller sebesar 18,311 ton/jam. Dari beberapa alat berat pada Pekerjaan Laston Lapis Antara (AC-BC) dengan Pekerjaan Laston Lapis Aus (AC-WC) terdapat perbedaan hasil produksi. Perbedaan produksi terjadi pada alat berat Asphalt Finisher, Tandem Roller dan Pneumatic Tire Roller. Hal ini disebabkan oleh perbedaan tebal lapis perkerasan yang dikerjakan pada pekerjaan AC-BC dan AC-WC. Volume pekerjaan dan produktivitas alat menetukan rencana durasi alat

Tabel 1. Rekapitulasi kapasitas produksi dan kebutuhan alat berat Pekerjaan AC-BC

\begin{tabular}{|c|c|c|c|c|}
\hline No & Peralatan & $\begin{array}{l}\text { Produkti- } \\
\text { vitas }(Q)\end{array}$ & $\begin{array}{c}\text { Jumlah } \\
\text { Alat } \\
\text { (n) }\end{array}$ & $\begin{array}{c}\text { Rencana } \\
\text { Durasi } \\
\text { Alat (Hari) }\end{array}$ \\
\hline 1 & $\begin{array}{l}\text { Asphalt } \\
\text { Mixing Plant }\end{array}$ & $\begin{array}{c}49,80 \\
\text { ton/jam }\end{array}$ & 1 & 21 \\
\hline 2 & Dump Truck & $\begin{array}{c}2,338 \\
\text { ton/jam }\end{array}$ & 9 & 21 \\
\hline 3 & $\begin{array}{l}\text { Air } \\
\text { Compressor }\end{array}$ & $\begin{array}{c}9,96 \\
\mathrm{~m}^{2} / \mathrm{jam}\end{array}$ & 1 & 28 \\
\hline 4 & $\begin{array}{l}\text { Asphalt } \\
\text { Sprayer }\end{array}$ & $\begin{array}{c}2.739 \\
\text { liter/jam }\end{array}$ & 1 & 28 \\
\hline 5 & $\begin{array}{l}\text { Asphalt } \\
\text { Finisher }\end{array}$ & $\begin{array}{l}109,181 \\
\text { ton/jam }\end{array}$ & 1 & 21 \\
\hline 6 & $\begin{array}{l}\text { Tandem } \\
\text { Roller }\end{array}$ & $\begin{array}{l}18,5505 \\
\text { ton/jam }\end{array}$ & 2 & 21 \\
\hline 7 & $\begin{array}{l}\text { Pneumatic } \\
\text { Tire Roller }\end{array}$ & $\begin{array}{l}27,467 \\
\text { ton/jam }\end{array}$ & 1 & 21 \\
\hline
\end{tabular}

Tabel 2. Rekapitulasi kapasitas produksi dan kebutuhan alat berat $\mathrm{AC}-\mathrm{WC}$

\begin{tabular}{llccc}
\hline No & Peralatan & $\begin{array}{c}\text { Produkti- } \\
\text { vitas (Q) }\end{array}$ & $\begin{array}{c}\text { Kebu- } \\
\text { tuhan } \\
\text { Alat } \\
\text { (n) }\end{array}$ & $\begin{array}{c}\text { Rencana } \\
\text { Durasi } \\
\text { Alat (Hari) }\end{array}$ \\
\hline 1 & $\begin{array}{l}\text { Asphalt } \\
\text { Mixing Plant }\end{array}$ & $\begin{array}{c}49,80 \\
\text { ton/jam }\end{array}$ & 1 & 14 \\
\hline 2 & Dump Truck & $\begin{array}{c}2,338 \\
\text { ton/jam }\end{array}$ & 13 & 14 \\
\hline 3 & $\begin{array}{l}\text { Air } \\
\text { Compressor }\end{array}$ & $\begin{array}{c}9,96 \\
\mathrm{~m}^{2} / \mathrm{jam}\end{array}$ & 1 & 21 \\
\hline 4 & $\begin{array}{l}\text { Asphalt } \\
\text { Sprayer }\end{array}$ & $\begin{array}{c}2.739 \\
\text { liter/jam }\end{array}$ & 1 & 21 \\
\hline 5 & $\begin{array}{l}\text { Asphalt } \\
\text { Finisher }\end{array}$ & $\begin{array}{c}72,787 \\
\text { ton/jam }\end{array}$ & 1 & 14 \\
\hline 6 & Tandem Roller & $\begin{array}{c}12,367 \\
\text { ton/jam }\end{array}$ & 3 & 14 \\
& & $\begin{array}{c}18,311 \\
\text { ton/jam }\end{array}$ & 2 & 14 \\
\hline 7 & $\begin{array}{l}\text { Pneumatic } \\
\text { Tire Roller }\end{array}$ & & & \\
\hline
\end{tabular}


REKOnSTRUKSI TADULAKO: Civil Engineering Journal on Research and Development, Vol. 2(1), March 2021

\subsection{Analisa Harga Alat dan Profit Pada Proyek} Pembangunan Infrastruktur Pendukung Sirkuit Mandalika

Berdasarkan hasil perhitungan diketahui Durasi (jam) kerja alat didapatkan dari hasil perkalian antara jumlah rencana durasi (hari) yang didapatkan dari hasil perhitungan dengan jam kerja dalam satu hari selama 8 jam (Tabel 4). Sehingga untuk alat $A M P$ dengan durasi 21 hari didapatkan 168 jam dan jumlah biaya sejumlah Rp. 368.779.908. Untuk alat berat dump truck dengan durasi 168 jam didapatkan jumlah biaya sejumlah Rp. 1.423.430.852. untuk alat berat air compressor dan asphalt sprayer yang berdurasi masingmasing selama 224 jam, didapatkan jumlah biaya masingmasing sebesar Rp. 99.760.017,5 dan Rp. 15.703.672,32. Sedangkan untuk alat asphalt finisher, tandem roller dan pneumatic tire roller dengan durasi masing-masing selama 168 jam didapatkan jumlah biaya masing-masing sejumlah Rp. 209.116.595,5 ; Rp. 126.569.908,8 ; dan Rp. 82.934.910,41.

Tabel 3. Perhitungan Harga Sewa Alat Berat Pada Pekerjaan Lapis Permukaan Jalan

\begin{tabular}{|c|c|c|c|c|}
\hline Pekerjaan & Peralatan & Jumlah Alat & $\begin{array}{l}\text { BOK per jam } \\
\text { (Rupiah) }\end{array}$ & $\begin{array}{c}\text { Biaya sewa perjam } \\
\text { (Rupiah) }\end{array}$ \\
\hline \multirow{7}{*}{$\begin{array}{l}\text { Laton Lapis Antara } \\
\qquad(\mathrm{AC}-\mathrm{BC})\end{array}$} & Asphalt Mixing Plant & 1 & $1.590 .343,58$ & $2.195 .118,5$ \\
\hline & Dump Truck & 9 & $7.461 .133,49$ & $8.472 .802,69$ \\
\hline & Air Compressor & 1 & $354.497,33$ & $445.357,22$ \\
\hline & Asphalt Sprayer & 1 & $55.625,04$ & $70.105,68$ \\
\hline & Asphalt Finisher & 1 & $729.004,39$ & $1.244 .741,64$ \\
\hline & Tandem Roller & 2 & $582.253,59$ & $753.392,31$ \\
\hline & Pneumatic Tire Roller & 1 & $408.666,08$ & $493.660,18$ \\
\hline \multirow{7}{*}{$\begin{array}{l}\text { Laton Lapis Aus } \\
\text { (AC-WC) }\end{array}$} & Asphalt Mixing Plant & 1 & $1.590 .343,58$ & $2.195 .118,5$ \\
\hline & Dump Truck & 13 & $10.777 .192,8$ & $12.238 .492,77$ \\
\hline & Air Compressor & 1 & $354.497,33$ & $445.357,22$ \\
\hline & Asphalt Sprayer & 1 & $55.625,04$ & $70.105,68$ \\
\hline & Asphalt Finisher & 1 & $729.004,39$ & $1.244 .741,64$ \\
\hline & Tandem Roller & 3 & $873.380,39$ & $1.130 .088,47$ \\
\hline & Pneumatic Tire Roller & 2 & $817.332,16$ & $987.320,36$ \\
\hline
\end{tabular}

Tabel 4. Analisa jumlah harga dan profit alat berat pada Pekerjaan Laston Lapis Antara (AC-BC)

\begin{tabular}{|c|c|c|c|c|c|c|c|}
\hline Jenis Alat & $\begin{array}{c}\text { Jumlah } \\
\text { Alat }\end{array}$ & Produksi & Volume & Durasi & $\begin{array}{c}\text { Biaya Sewa } \\
\text { Alat Per } \\
\text { Jam (Rp.) }\end{array}$ & Harga & Jumlah Biaya \\
\hline$A M P$ & 1 & 49.8 & $3,554.61$ & 168 & $2,195,118.50$ & $43,902.37$ & $368,779,908$ \\
\hline Dump Truck & 9 & 2.338 & $3,554.61$ & 168 & $941,422.52$ & $4,041,526.88$ & $1,423,430,852$ \\
\hline Air Compressor & 1 & 9.96 & $30,643.20$ & 224 & $445,357.22$ & $44,535.72$ & $99,760,017.50$ \\
\hline Asphalt Sprayer & 1 & 2,739 & $30,643.20$ & 224 & $70,105.68$ & 25.595 & $15,703,672.32$ \\
\hline Asphalt Finisher & 1 & 109.181 & $3,554.61$ & 168 & $1,244,741.64$ & $11,400.72$ & $209,116,595.50$ \\
\hline Tandem Roller & 2 & 18.5505 & $3,554.61$ & 168 & $376,696.16$ & $40,607.85$ & $126,569,908.80$ \\
\hline $\begin{array}{l}\text { Pneumatic Tire } \\
\text { Roller }\end{array}$ & 1 & 27.467 & $3,554.61$ & 168 & $493,660.18$ & $17,969.23$ & $82,934,910.41$ \\
\hline \multicolumn{4}{|c|}{ Jumlah Harga Peralatan } & & & & $2,326,295,864$ \\
\hline \multicolumn{4}{|l|}{ PPN } & & \multicolumn{2}{|c|}{$10 \% \times$ Jumlah Harga Alat } & $23,262,958.64$ \\
\hline \multicolumn{4}{|c|}{ Jumlah Harga + PPN } & & \multirow{2}{*}{\multicolumn{2}{|c|}{$10 \% \times($ Jumlah Harga + PPN $)$}} & $2,349,558,823$ \\
\hline \multicolumn{4}{|l|}{ Profit } & & & & $2.34 .955 .882,3$ \\
\hline $\begin{array}{ll}\text { Jumlah } & \text { Biaya } \\
\text { Pekerjaan } & \end{array}$ & & & & & \multicolumn{2}{|c|}{ Jumlah Harga + PPN + Profit } & $2,584,514,705$ \\
\hline
\end{tabular}

Harga satuan alat dapat dihitung dengan mengalikan koefisien alat dan harga sewa alat dengan rumusan berdasarkan panduan analisis harga satuan Bina Marga, dimana koefisien alat didapat dari 1/produksi alat berat. Jumlah biaya peralatan alat berat didapatkan dari perkalian jumlah alat, durasi dan biaya sewa alat. Besar biaya dari penggunaan alat berat pada Pekerjaan Laston Lapis Antara (AC-BC) adalah Rp. 2.584.514.705.
Berdasarkan hasil perhitungan diketahui Durasi (jam) kerja alat didapatkan dari hasil perkalian antara jumlah rencana durasi (hari) yang didapatkan dari hasil perhitungan dengan jam kerja dalam satu hari selama 8 jam. Sehingga untuk alat $A M P$ dengan durasi 14 hari didapatkan 112 jam dan jumlah biaya sejumlah Rp. 197.545.813,9. Untuk alat berat dump truck dengan durasi 112 jam didapatkan jumlah biaya sejumlah Rp. 1.370.711.191. untuk alat berat air compressor dan asphalt sprayer yang berdurasi masing- 
masing selama 168 jam, didapatkan jumlah biaya masingmasing sebesar Rp. 47.668.148,81dan Rp. 11.777.754,24. Sedangkan untuk alat asphalt finisher, tandem roller dan pneumatic tire roller dengan durasi masing-masing selama 112 jam didapatkan jumlah biaya masing-masing sejumlah Rp. 139.411.063,7; Rp. 91.845.519,36; dan Rp. 110.579.880,5. Harga satuan alat dapat dihitung dengan mengalikan koefisien alat dan harga sewa alat dengan rumusan berdasarkan panduan analisis harga satuan Bina Marga, dimana koefisien alat didapat dari 1/produksi alat berat. Jumlah biaya peralatan alat berat didapatkan dari perkalian jumlah alat, durasi dan biaya sewa alat. Besar biaya dari penggunaan alat berat pada Pekerjaan Laston Lapis Aus (AC-WC) adalah Rp. 2.383.142.639.

Tabel 5. Analisa jumlah harga dan profit alat berat pada Pekerjaan Laston Lapis Aus (AC-WC)

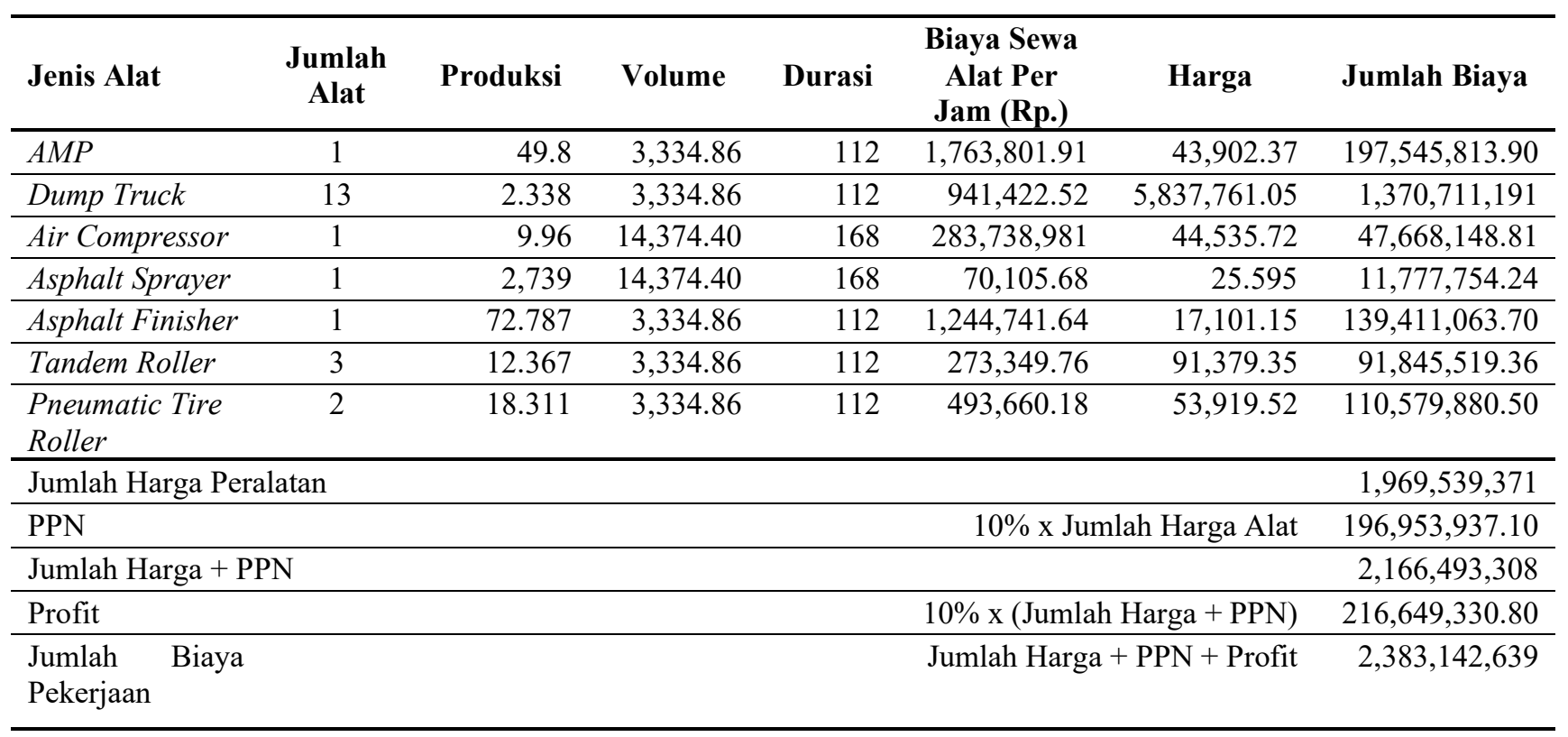

Dari hasil analisa dan perhitungan diperoleh jumlah biaya penggunaan alat berat pekerjaan lapis permukaan jalan ruas E-R-S-T dengan hasil penjumlahan biaya pekerjaan laston lapis antara (AC-BC) dan pekerjaan laston lapis aus (ACWC) didapatkan sejumlah Rp. 4.967.657.344. Sedangkan jumlah biaya penggunaan alat berat pada pekerjaan lapis permukaan jalan ruas E-R-S-T pada dokumen kontrak sebesar Rp. 5.042082.622. Selisih biaya antara hasil pehitungan dengan nilai kontrak sebesar Rp. 74.425.278. Selisih biaya ini diindikasikan dapat terjadi karena kebutuhan jumlah alat yang diperoleh pada hasil perhitungan berbeda dengan jumlah alat yang digunakan di proyek.

\section{Kesimpulan}

Berdasarkan analisis yang telah dilakukan, terdapat beberapa kesimpulan dari penelitian ini, sebagai berikut:

1) Alat berat yang digunakan pada pekerjaan lapis permukaan jalan (surface) adalah Asphalt Mixing Plant (AMP) LB 1000, Dump Truck merek Hino, Air Compressor merek Airman, Asphalt Sprayer merek Rutra, Asphalt Finisher merek Sumitomo, Tandem Roller merek Junma dan Pneumatic Tire Roller merek Sakai.

2) Produktivitas alat berat yang dihitung merupakan produksi nyata dilapangan. Produksi yang dihasilkan pada pekerjaan AC-BC yaitu untuk 1 unit Asphalt Mixing Plant adalah 49,80 ton/jam, 9 unit Dump Truck = 2,338 ton/jam, 1 unit Air Compressor $=9,96 \mathrm{~m}^{2} / \mathrm{jam}$, 1 unit Asphalt Sprayer $=2.739$ liter/jam, 1 unit Asphalt
Finisher $=109,181$ ton/jam, 2 unit Tandem Roller = 18,5505 ton/jam, dan 1 unit Pneumatic Tire Roller $=$ 27,467 ton/jam. Sedangkan pada pekerjaan AC-WC yaitu untuk 1 unit Asphalt Mixing Plant $=49,80$ ton/jam 13 unit Dump Truck $=2,338$ ton/jam, 1 unit Air Compressor $=9,96 \mathrm{~m}^{2} / \mathrm{jam}, 1$ unit Asphalt Sprayer $=$ 2.739 liter/jam, 1 unit Asphalt Finisher =72,787 ton/jam, 3 unit Tandem Roller $=12,367$ ton/jam, dan 1 unit Pneumatic Tire Roller $=18,311$ ton $/ \mathrm{jam}$.

3) Total biaya penggunaan alat berat pada pekerjaan lapis permukaan jalan berdasarkan hasil perhitungan adalah sebesar Rp. 4.967.657.344. Total biaya penggunaan alat berat berdasarkan dokumen kontrak adalah sebesar Rp 5.042.082.622. Sehingga selisih biaya sebesar Rp. 74.425 .278 .

\section{Daftar Pustaka}

[1] I.A. Syauki, R.T. Iriana, and A. Malik, “Analisis Biaya Pemakaian Alat Berat pada Proyek Rekontruksi Jalan Batas Kota Pariaman-Manggopoh Kabupaten Padang Pariaman Provinsi Sumatera Barat", Jurnal Online Mahasiswa Fakultas Teknik Universitas Riau, vol. 5, no. 1, p. 1, 2018.

[2] S. D. Hartantyo, "Pengaruh Efisiensi Alat Berat Pada Pekerjaan Jalan Proyek Pembenahan Pabrik Asam Phospat PT. Petrokimia Gresik Jawa Timur", Extrapolasi: Jurnal Teknik Sipil, vol. 8, no. 2, p. 137 , 2015. 
[3] M. Fauzan, M. Mukhlis, and M. Danil, "Tinjauan Biaya Penggunaan Alat Berat Pada Proyek Pengaspalan Jalan Ujong Pacu-Cot Trieng Kecamatan Muara Satu Kota Lhokseumawe", Teras Jurnal: Jurnal Teknik Sipil, vol. 4, no. 2, p. 1, 2014.

[4] E.N. Kulo, J.E. Waani, and O.H. Kaseke, “Analisa Produktivitas Alat Berat Untuk Pekerjaan Pembangunan Jalan (Studi Kasus : Proyek Pembangunan Jalan Lingkar SKPD Tahap 2 Lokasi Kecamatan Tutuyan Kabupaten Bolaang Mongondow Timur)", Jurnal Sipil Statik, vol. 5, no. 7, p. 465, 2017.

[5] D.S.H. Effendi, "Perhitungan Kebutuhan Alat Berat Pada Pekerjaan Tanah Proyek Pembangunan Pabrik Precast di Sentul", Jurnal Online Mahasiswa (JOM) Bidang Teknik Sipil, vol. 1, no.1, p. 1, 2016.

[6] D. Febrianti and Z. Zulyaden, "Analisis Produktivitas Alat Berat Pada Pekerjaan Timbunan”, Jurnal Teknik Sipil dan Teknologi Konstruksi, vol. 4, no.1, p. 21, 2018.

[7] D.D. Supit, "Analisa Produktivitas dan Efisensi Alat Berat Untuk Pekerjaan Tanah, Dan Pekerjaan Perkerasan Berbutir" Journal Dynamic Saint, vol. 5, no.1, p. 906, 2020.

[8] R. Primayandhi, "Studi Perhitungan Kebutuhan Alat Berat dan Biaya Lapis Pondasi Aggregat Kelas A Pada Jalan Sepunggur-Gunung Tinggi Kab. Tanah Bumbu”, vol. 2, no. 1, p. 47, 2014.

[9] A. Rizal, M. Fajri, and L.S. Yuniar, "Estimasi Biaya Konstruksi Pada Perumahan Tipe 45 di Sulawesi Tengah Menggunakan Regresi Kuadratik”, Rekonstruksi Tadulako: Civil Engineering Journal on Research and Development, vol. 1, no. 2, p. 31, 2020.

[10] M. Asri, J. Siddik, and S. Supardin, "Tinjauan Rencana Anggaran Biaya dan Waktu Pelaksanaan Pada Proyek Peningkatan Jalan Matang Ben-Pulo Blang Kabupaten Aceh Utara", Jurnal Sipil Sains Terapan, vol. 2, no. 2, p. 56, 2018.
[11] Departemen Pekerjaan Umum, Peralatan, Jakarta: Direktorat Jendral Bina Marga, 2016.

[12] Kementrian Pekerjaan Umum, Analisa Harga Satuan Pekerjaan (AHSP), Jakarta: Direktorat Jendral Bina Marga, 2013.

[13] A. Kholil, Alat Berat, Bandung: PT. Remaja Rosdakarya, 2012.

[14] Meikusyadi, Analisa Produktivitas dan Biaya Alat Berat Pada Pekerjaan Lapis Permukaan Jalan (Surface) Proyek Pembangunan Jalan Gerung (Patung Sapi) - Mataram 2 Menggunakan Metode Bina Marga, Mataram: Universitas Mataram, 2016.

[15] S.F. Rostiyanti, Alat Berat Untuk Proyek Konstruksi Edisi 2. Jakarta: Rineka Cipta, 2008.

[16] D.N. Setiawati and A. Maddeppunggeng, Analisis Produktivitas Alat Berat Pada Proyek Pembangunan Pabrik Krakatau Posco Zone IV di Cilegon, Serang: Universitas Sultan Ageng Tirtayasa, 2013.

[17] S. Sukirman, Perkerasan Lentur Jalan Raya, Bandung: Nova, 1999.

[18] H. Suryadharma, Wigroho, and H. Yoso, Alat-Alat Berat, Yogyakarta: Universitas Atma Jaya, 1999.

[19] S.P. Tauro, Analisa Biaya Penggunaan Alat Berat Pada Pekerjaan Tanah (Studi Kasus Perencanaan Bandar Udara Lokasi Desa Pusingi Kec. Ampena Tete Kab. Tojo Una-una, Sulawesi Tengah, Manado: Universitas Sam Ratulangi, 2013.

[20] F. Bakrie, "Perencanaan Biaya dan Metode Pelaksanaan Pada Jalan Pameu-Genting Gerbang Kabupaten Aceh Tengah", Portal, vol. 8, no. 2, p. 29, 2018. 
This page is intentionally left blank 